\title{
From London to Oxford
}

It is with mixed feelings that I have to announce changes to the Journal's publication arrangements.

I am saddened to find that the exigencies of modern trading dictate that our Journal is obliged to move - at very short notice - from its London office to the group headquarters of Butterworth-Heinemann at Oxford. Unfortunately this means the loss of my entire editorial team, who have worked so hard to achieve our present level of punctual production.

Contributors will know of Alison Cherrie's helpful efficiency with their manuscripts. She has revolutionized our computerized logging system - not so long ago dependent on my home PC - and this has been central to the faster processing and refereeing of manuscripts. It may not be appreciated that modern journal production involves a complex timetabling of editorial, illustrative, printing and production work, often with geographical separation of those responsible for each stage and our Editorial Controller, Heather Walmsley, has coped cheerfully with all this.

My senior colleagues, Sarah Graham-Campbell, Managing Editor, and Elizabeth Royall, Assistant Editor, have not only been tolerant of my wilder flights of fancy (and even humoured some of them!), but brought essential discipline to the editorial process as we struggled to bring ourselves up to date after joining Butterworths at Guildford and then having to move to London with Butterworth-Heinemann. I can only express my gratitude to my team and pledge that I will make every effort to ensure that their firm base is successfully built upon. I wish them each success in their futures.

On the positive side is the assurance that as Butterworth-Heinemann is now part of the international conglomerate Reed Elsevier, we can count on a stronger base for expansion at the heart of the group headquarters. This will bring us more staff and the advantages of group support.

The London office will be closed by the time this is read and the Oxford office will be in the capable hands of Sue Deeley, Medical Journals Group Publisher. Details are given below.

I can only apologise for the shortage of notice of major change given to us all. While we have made every effort to ensure a smooth transition, a few hiccups will be inevitable (we still receive correspondence at Guildford and I still receive BASM Secretarial letters - a post I vacated ten full years ago!). However, we will be able to bring you developments that were difficult to achieve independently.

On the happy side, I am delighted to welcome two distinguished colleagues to the Editorial Board. Dr Kai-Ming Chan has given invaluable input to the Journal already and is President of the Asian Federation of Sports Medicine. Professor Craig Sharp, widely regarded abroad, cannot be unknown to anybody concerned with Sports Medicine in the UK and has given us much editorial help since 1989 .

We leave London for Oxford with a full portfolio of papers, a healthy rejection rate suggesting emphasis on gradually increasing quality, punctual publication and a growing circulation.

Peter Sperryn

Editor-in-Chief

\section{URGENT ANNOUNCEMENT}

The London office of BJSM is closed. ALL communications should now be addressed to:

\author{
BRITISH JOURNAL OF SPORTS MEDICINE \\ Butterworth-Heinemann \\ Linacre House \\ Jordan Hill \\ OXFORD OX2 8DP, UK
}

BJSM direct phone: $+44(0) 865314512$

BJSM direct fax: $\quad+44(0) 865314557$

All enquiries to: SUE DEELEY, Publisher, Medical Journals 